\title{
Gender Differences in Forgiveness and its Affective Correlates
}

\section{Kinga Kaleta ${ }^{1}$ D . Justyna Mróz ${ }^{1}$}

Accepted: 22 July 2021 / Published online: 6 August 2021

(C) The Author(s) 2021

\begin{abstract}
Although women are believed to be more forgiving than men, the results of many studies comparing women with men vary. Moreover, little is known about unique correlates or differential patterns of experiencing forgiveness by gender. In the present study, we compared men and women in terms of their level of dispositional forgiveness and its emotional correlates, namely positive and negative affect, anxiety, and emotional control. The sample consisted of 625 individuals aged 19-69, of whom $478(76.5 \%)$ were women and 147 (23.5\%) were men. Polish versions of the Heartland Forgiveness Scale (HFS), the Positive and Negative Affect Schedule (PANAS), the Courtauld Emotional Control Scale (CECS), and the State-Trait Anxiety Inventory (STAI) were used. Men showed a higher level of general forgiveness and greater willingness to overcome unforgiveness than women, but there was no significant difference in positive facets of the disposition to forgive. In both genders negative affect, anxiety, and control of anger and of depression were negatively related to dimensions of dispositional forgiveness, and positive affect was positively associated with forgiveness. In females control of anxiety was negatively and in males it was positively related to facets of forgiveness. Gender moderated a number of links between affective traits and forgiveness of self and of situations beyond control, but not forgiveness of others.
\end{abstract}

\section{Introduction}

Women are generally believed to be more forgiving than men, due to their personality traits such as agreeableness and empathy, and their valuing relationships (Miller et al., 2008). In a meta-analytic review of 70 studies with 15,731 individuals, Miller

Kinga Kaleta

k_kaleta@wp.pl

Justyna Mróz

justyna_mroz@wp.pl

1 Department of Psychology, The Jan Kochanowski University, ul. Krakowska 11, 25-029 Kielce, Poland 
et al. (2008) found a gender difference in forgiveness with small to moderate effect size, showing greater willingness to forgive among female respondents. On the other hand, Fehr et al. (2010) who conducted meta-analyses across 53 studies with the total number of 8,366 participants, found no relationships between gender and forgiveness. There are many reasons for this discrepancy between findings reported by different researchers, including methodological approach, but the main one is the fact that majority of referenced studies were not aimed at comparing men and women in terms of multidimensional forgiveness and the way they experience this phenomenon. Also, very few attempts have been made to find unique correlates or differential patterns of experiencing forgiveness by genders (e.g., Toussaint \& Webb, 2005). Thus, in the present study we directly compare males and females in terms of their level of dispositional forgiveness and its emotional correlates, namely positive and negative affect, anxiety, and emotional control, and we examine the moderating role of gender in the relationships between emotions and forgiveness.

\section{Forgiveness-Disposition and Gender Differences}

Most researchers agree that forgiveness is a complex construct (Enright \& Fitzgibbons, 2000). It involves cognitive (Flanigan, 1992; Gordon \& Baucom, 1998; Thompson et al., 2005), affective (Worthington \& Scherer, 2004), motivational (McCullough et al., 1997), decisional (DiBlasio, 1998), and interpersonal (e.g., Baumeister et al., 1998) aspects. It is usually defined as a process of reducing negative thoughts, feelings, and behaviors toward a transgressor (Enright, 1996; McCullough et al., 1998; Rye \& Pargament, 2002) which might be accompanied by evoking positive thoughts, feelings, and actions toward the harm-doer (Sells \& Hargrave, 1998; Subkoviak et al., 1995). Thus, forgiveness occurs via shift in beliefs, affects, and motives (see Toussaint \& Friedman, 2009; Fehr et al., 2010).

Forgiveness conceptualized in this manner might be viewed not only as a single act following a particular offense, but also as a dimension of personality (Hill \& Allemand, 2010; Kamat, et al., 2006). The latter (also referred to as forgivingness; Roberts, 1995) can be defined as one's tendency to forgive regardless of time, relationships, and situations (Berry et al., 2001; Brown, 2003) and is mainly related to other personality traits, such as agreeableness (Berry et al., 2001; Kamat et al., 2006), neuroticism (Allemand et al., 2008; Maltby et al., 2004), religiousness (Brown et al., 2007; Edwards et al., 2002), empathy (Brown, 2003; Chung, 2014; Giammarco \& Vernon, 2014), gratitude (McCullough et al., 2002; Touissant \& Friedman, 2009), cognitive flexibility (Thompson et al., 2005), rumination (Berry et al., 2005; Burnette et al., 2009; Chung, 2014), or narcissism (Brown, 2004; Eaton et al., 2006; Fatfouta et al., 2015). Many of these personality characteristics are usually gender-specific, which suggests that dispositional forgiveness might also differ depending on gender. A similar suggestion might be drawn from the previous meta-analytic reviews (Miller \& Worthington, 2015; Miller et al., 2008).

However, the results of studies comparing dispositional forgiveness in men and women are ambiguous. For instance, $\mathrm{Ka}$ et al. (2006) found that women yielded 
significantly higher scores on the Forgiving Personality Scale. Also, Mullet et al. (1998) found that women, more than men, were prone to forgive rather than to seek revenge. Toussaint et al. (2008) showed forgiveness of others, feeling forgiven by God and seeking forgiveness to be greater among females than males. In turn, Brown (2003) revealed that women scored lower than men in the tendency to forgive. Moreover, studies have reported that the observed relationships between different variables and forgivingness vary notably as a function of the participants' genders. Neto and Mullet (2004) showed that the relationship between self-esteem and propensity to forgive was positive in men, but negative among women. Ryan and Kumar (2005) found willingness to forgive significantly correlated with anxiety and symptoms severity in males, but not in females. Toussaint et al. (2008) showed that for women, high levels of forgiveness of others, forgiveness of self, feeling forgiven by God, and seeking forgiveness significantly reduced the odds of major depressive symptoms, while for men, only forgiveness of self was a significant predictor of depression. On the other hand, several studies (Berry et al., 2001; Brose et al., 2005; Cohen et al., 2006) found no gender differences in disposition to forgive. Thus, gender differences in forgivingness deserve to be more directly addressed (Miller $\&$ Worthington, 2015), the more so that the existing literature provides theoretical and empirical framework for putting forward specific hypotheses. They might be derived from concepts and research on interpersonal orientation and affective traits (cf. Miller et al., 2008; Toussaint et al., 2008).

\section{Conceptual Framework}

Many gender differences in cognition, motivation, emotion, and social behavior may be explained in terms of men's and women's different self-construals (Markus \& Kitayama, 1991). Male self-construals are typically more independent, autonomous, distinct, and separated from others, while female self-construals are more interdependent, connected, and less differentiated from others (Agerström et al., 2006; Cross \& Madson, 1997). Such differences in defining oneself may have an impact on gender differences in responding to and dealing with transgressions. Women are likely to be more motivated to forgive because forgiveness helps them maintain a connection with others (Markus \& Kitayama, 1991) by pushing people to reconciliation (Worthington et al., 2019). The link between interdependence and forgivingness was found to be notably stronger among women than men (Neto \& Mullet, 2004). It might be particularly important when female stress and detachment following interpersonal transgressions are intensive and an individual needs to cope with them. Although there are different ways to reduce such distress (Wade \& Worthington, 2003), only forgiveness results in pro-social acting and relating with others (Worthington \& Wade, 1999). In confirmation, Neto and Mullet (2004) showed that loneliness was positively associated with propensity to forgive among women, whereas it was negatively correlated in men (Neto \& Mullet, 2004).

Gender and different self-construals might not only affect the level of forgiveness, but they may also play a role in processing forgiveness, especially in the relationship between emotions and forgiveness. Different self-construals bring significant 
consequences for experiencing or/and suppressing emotions, both positive and negative (Markus \& Kitayama, 1991). For instance, holding an interdependent view of the self inhibits overly expressed anger or frustration, which are emotional states closely related to forgiveness. Consequently, links between the tendency to experience and control different emotions and the ability to forgive might differ in men and women. Generally, negative affect and emotions such as anger, shame, and guilt may impede the process of forgiveness (Hall \& Fincham, 2008; Macaskill, 2012; Mróz \& Kaleta, 2017), and less forgiving individuals tend to experience higher levels of bitterness, hostility, fear, anxiety, or depressive affect (Barcaccia et al., 2020; Berry et al., 2005; Rye et al., 2001; Toussaint et al., 2008; Lawler-Row \& Piferi, 2006; Burnette et al., 2009). In turn, positive emotions, like sympathy, compassion, or happiness, increase the likelihood of forgiving (Baker et al., 2017; Uysal \& Satici, 2014). Still, there are gender differences in various affective traits. For instance, women often score higher in negative affect, especially for anxiety and depression (Fujita et al., 1991; Parker \& Brotchie, 2010; Thomsen et al., 2005). In addition, emotion regulation which affects emotional experience and expression (Baker et al., 2017; Gross, 1998; Gross \& John, 2003; Thomsen et al., 2005) and which is related to forgiveness (Baker et al., 2017; Hodgson \& Wertheim, 2007; Mami et al., 2019; McCullough et al., 2001; Witvliet et al., 2010, 2011, 2015), might be gender-related (Gross \& John, 2003; Koch et al., 2007; Matud, 2004; McRae et al., 2008; Thomsen et al., 2005). Summing up, our reasoning points to gender differentiation in forgivingness and its associations with emotional variables. Thus, the first goal of the present study was to examine gender differences in the levels of dispositional forgiveness. We put forward the hypothesis that women would score higher in multiple dimensions of forgivingness (H1). The second goal was to examine how emotional variables are associated with different aspects of dispositional forgiveness among women and men. We expected that negative affect, anxiety and control of anger, of depression and of anxiety, would be significantly and inversely correlated with forgivingness, whereas positive affect positively correlated with the ability to forgive in both genders. However, as shown, the link between emotionality and dispositional forgiveness may vary across genders in terms of direction or magnitude. Thus, we hypothesized the moderating role of gender in the analyzed relationships. From the self-construal approach positive emotions might motivate females to be more forgiving than men, whereas the experience of negative emotions may make women less reluctant than men to forgive in order to find peace after transgressions. Consequently, we hypothesized that the relationship between positive affect and dispositional forgiveness would be more positive for females (H2), while associations between negative affect and forgiveness, anxiety and forgiveness, and between suppression of emotions and forgiveness would be less negative for them (H3). 


\section{Method}

\section{Participants}

Data were collected from 638 adults, 481 women (75.4\%), and 148 men (23.2\%). Nine participants did not specify their gender. They were from 19 to 69 years of age, with the mean age of $33.45(\mathrm{SD}=11.81)$. The majority of respondents were married (49\%), $1.7 \%$ widowed, $4.3 \%$ divorced, and $45 \%$ never married. Educational attainment ranged from vocational education $(21.1 \%)$, through secondary $(24.8 \%)$, and college $(14.8 \%)$ to higher education $(39.3 \%)$. Finally, $48.4 \%$ of the respondents lived in the country, $16.1 \%$ in towns, and $35.4 \%$ in cities.

\section{Measures}

\section{Forgivingness}

Disposition to forgive was measured using the Polish version (Kaleta et al., 2016) of the Heartland Forgiveness Scale (Thompson \& Snyder, 2003; Thompson et al., 2005). HFS is a multidimensional tool assessing dispositional forgiveness of self, others, and situations beyond anyone's control. Participants rate their responses to 18 items on a 7-point scale. The Polish version consists of two scales that allow to measure forgivingness in two separate domains-positive (P-scale; benevolent thoughts, feelings, and behaviors) and negative (N-scale; reduction of hostile thoughts, feelings, and behaviors), and six subscales with the distinction of forgiveness of self, others, and situations (P-self, P-others, P-situations, N-self, N-others, $\mathrm{N}$-situations). Higher scores on each scale reflect a higher level of forgivingness in every domain. The total HFS score indicates how forgiving a person tends to be. Sample items include "Although I feel badly at first when I mess up, over time I can give myself some slack" and "If others mistreat me, I continue to think badly of them." Cronbach's alpha (internal consistency) values were found as follows: for overall HFS 0.76 , for P-scale 0.70 , and for N-scale 0.81 , and from 0.50 to 0.81 for subscales (Kaleta et al., 2016).

\section{Positive and Negative Affect}

Positive-negative affect was measured using the Polish version (SUPIN C30; Brzozowski, 2010) of the Positive and Negative Affect Schedule (PANAS; Watson et al., 1988). The scale consists of 30 items, 15 items for positive affect (from 15 to 75 points) and 15 items for negative affect (from 15 to 75 points). We focused on measuring affect at a trait level. Using a 5-point scale, the participants are asked to indicate the degree to which they usually feel each emotion, e.g., ashamed, irritated, afraid, exited, proud, active. The higher the score, the higher the level of particular affectivity. Cronbach's alpha for PANAS ranged from 0.73 to 0.95 (Brzozowski, 2010). 


\section{Anxiety}

Anxiety was measured using the State-Trait Anxiety Inventory (STAI, Spielberger et al., 1983), more specifically the Polish version of the tool (Wrześniewski et al., 2002). This is a widely used, valid instrument. In the present study, participants rated 20 trait anxiety items (STAI-X2) assessing how an individual generally feels, using a 4-point Likert scale. Sample items: "I worry too much over something that really doesn't matter," "I am a steady person." The score range is from 20 (low) to 80 (high anxiety). Cronbach's alpha measuring internal consistency of the Polish version ranged from 0.76 to 0.92 in the group of adult women and men.

\section{Emotional control}

Emotional control was measured using the Courtauld Emotional Control Scale (CECS) developed by Watson and Greer (1983) and adapted in Poland by Juczyński (2009). The questionnaire allows to evaluate the extent to which individuals report suppression as an emotion regulation strategy in difficult situations. The CECS consists of 21 items divided into three subscales, each of which contains seven statements concerning the way of suppressing or expressing anger, depression and anxiety (from 7 to 28 points in every subscale). Participants are asked to respond to the phrases "When I feel angry...", "When I feel anxious (worried)...", and "When I feel unhappy (miserable)..." with statements such as "I keep quiet," "I bottle it up," or "I tell others about it" rated on a 4-point scale. The total emotional control index is established by summing up the results of the three subscales. The higher the result, the more negative emotions are suppressed. Reliability of the Polish version (Cronbach's alpha) is: for the control of anger 0.80, depression 0.77 , anxiety 0.78 , and for the total emotional control 0.87 (Juczyński, 2009).

\section{Statistical methods}

First, we calculated descriptive statistics (means and standard deviations) for all the variables in women and men separately. Due to unequal sample sizes we used the Mann-Whitney $U$ test to examine gender differences and the Glass' $\Delta$ estimate to evaluate the effect size. Second, correlational analyses were performed to explore relationships among emotional variables and multidimensional forgiveness in females and males. Finally, to test whether gender moderated the relationship between emotionality and disposition to forgive, we used a set of moderation analyses using the Process macro for SPSS (Model 1, version 3.5, Hayes, 2018). Moderation models have been proposed with positive-negative affect, anxiety, emotional control (overall and control of anger, of anxiety, and of depression) as predictors, dimensions of forgivingness as outcome variables, and gender as a moderator. In order to properly estimate interactions of emotional variables and gender on forgivingness, mean centering and standardizing were applied. Bias-corrected confidence intervals (CI 95\%) and the bootstrapping procedure (samples $=5000)$ were used to calculate direct and indirect effects. 
Table 1 Mean levels and standard deviations of dispositional forgiveness and affective traits by gender

\begin{tabular}{|c|c|c|c|c|c|c|c|}
\hline & \multicolumn{2}{|c|}{$\begin{array}{l}\text { Women } \\
(n=476)\end{array}$} & \multicolumn{2}{|c|}{$\operatorname{Men}(n=146)$} & \multirow[t]{2}{*}{ Mann-Whitney $U$} & \multirow[t]{2}{*}{$p$} & \multirow[t]{2}{*}{ Glass' $\Delta$} \\
\hline & $M$ & $S D$ & $M$ & $S D$ & & & \\
\hline Total forgiveness & 81.94 & 12.15 & 84.22 & 11.48 & $30,638.00$ & .030 & -.19 \\
\hline Positive forgiveness (P-scale) & 44.23 & 6.74 & 43.80 & 6.77 & $33,321.00$ & .452 & .06 \\
\hline P-self & 15.05 & 2.98 & 14.82 & 3.09 & $33,907.00$ & .656 & .07 \\
\hline P-others & 14.18 & 3.06 & 13.86 & 3.06 & $32,864.00$ & .319 & .10 \\
\hline P-situations & 15.01 & 2.84 & 15.12 & 2.91 & $33,728.50$ & .509 & -.04 \\
\hline Reduced unforgiveness (N-scale) & 37.71 & 9.30 & 40.42 & 9.59 & $29,224.00$ & .004 & -.28 \\
\hline N-self & 12.27 & 4.37 & 13.62 & 4.39 & $28,510.50$ & .001 & -.31 \\
\hline N-others & 12.95 & 3.61 & 12.97 & 3.68 & $33,522.00$ & .542 & -.01 \\
\hline $\mathrm{N}$-situations & 12.49 & 3.89 & 14.01 & 3.67 & $26,825.50$ & .000 & -.41 \\
\hline Positive affect & 48.07 & 9.35 & 50.45 & 10.49 & $29,247.00$ & .009 & -.27 \\
\hline Negative affect & 35.32 & 11.96 & 29.02 & 10.40 & $23,577.50$ & .000 & .61 \\
\hline Anxiety & 46.50 & 9.21 & 41.18 & 9.37 & $21,296.50$ & .000 & .57 \\
\hline Emotional control - total score & 50.17 & 10.99 & 53.23 & 9.70 & $27,061.50$ & .000 & -.32 \\
\hline Control of anger & 15.97 & 4.69 & 16.43 & 4.37 & $31,869.50$ & .237 & -.11 \\
\hline Control of depression & 17.27 & 4.35 & 17.84 & 3.76 & $31,098.50$ & .110 & -.15 \\
\hline Control of anxiety & 16.93 & 4.28 & 18.95 & 4.50 & $24,467.50$ & .000 & -.45 \\
\hline
\end{tabular}

\section{Results}

Table 1 presents gender differences in dimensions of forgivingness and analyzed variables and provides descriptive statistics, statistical significance, and Glass' $\Delta$ effect size estimates.

Men showed higher levels of general forgivingness and more willingness to overcome unforgiveness, especially toward oneself and situations beyond anyone's control. Gender did not differentiate the results in positive facets of the disposition to forgive. There were gender differences in affective traits. Women scored significantly higher in negative affect and anxiety. Men reported greater positive affect and emotional control, in particular the suppression of anxiety. It should be noted that according to the Glass' effect size estimate, gender differences were rather small to moderate in magnitude. The largest differences between women and men were reported for reduced unforgiveness of situations, negative affect, anxiety, and control of anxiety.

Table 2 shows correlations (Pearson's r) between the variables in women and men. 


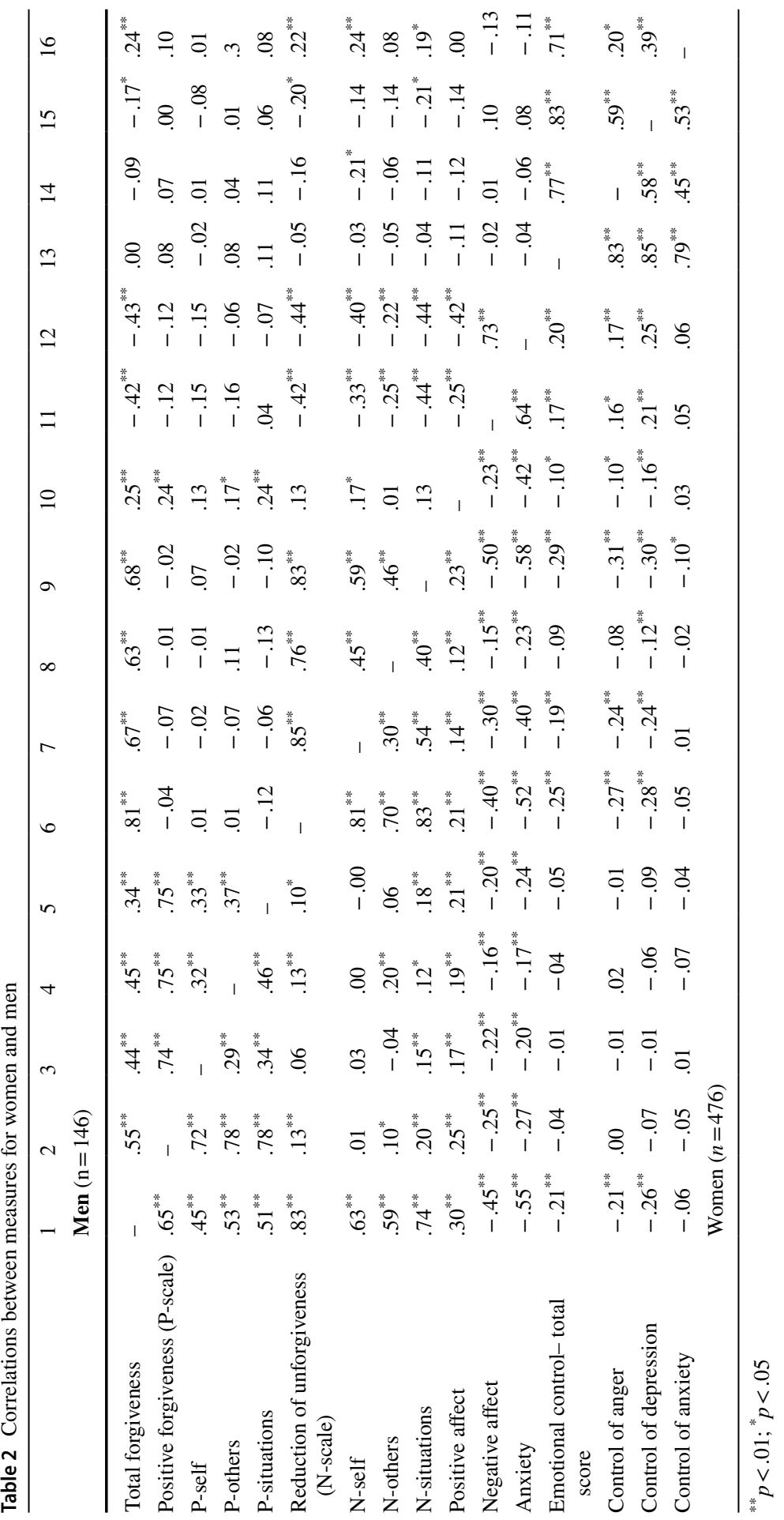


Table 3 Indirect effects of affective variables on forgivingness moderated by gender

\begin{tabular}{|c|c|c|c|c|c|c|c|}
\hline \multicolumn{2}{|c|}{ Moderating role of gender } & \multicolumn{6}{|c|}{ Indirect effects } \\
\hline Predictors & Outcomes & $B$ & $S E$ & $\Delta R 2$ & $F$ & LLCI & ULCI \\
\hline \multirow[t]{9}{*}{ Positive affect } & Total forgiveness & -.114 & .108 & .002 & 1.115 & -.327 & .098 \\
\hline & $\begin{array}{l}\text { Positive forgiveness } \\
\text { (P-scale) }\end{array}$ & -.024 & .062 & .000 & .153 & -.145 & .097 \\
\hline & P-self & -.018 & .028 & .001 & .391 & -.073 & .038 \\
\hline & P-others & -.011 & .028 & .000 & .154 & -.067 & .044 \\
\hline & P-situations & .005 & .026 & .000 & .029 & -.047 & .056 \\
\hline & $\begin{array}{l}\text { Reduction of unforgiveness } \\
(\mathrm{N} \text {-scale })\end{array}$ & -.090 & .087 & .002 & 1.080 & -.260 & .080 \\
\hline & $\mathrm{N}$-self & .003 & .041 & .000 & .007 & -.077 & .083 \\
\hline & $\mathrm{N}$-others & -.045 & .034 & .003 & 1.760 & -.112 & .022 \\
\hline & $\mathrm{N}$-situations & -.048 & .035 & .003 & 1.882 & -.118 & .021 \\
\hline \multirow[t]{9}{*}{ Negative affect } & Total forgiveness & -.011 & .097 & .000 & .012 & -.200 & .179 \\
\hline & $\begin{array}{l}\text { Positive forgiveness } \\
\text { (P-scale) }\end{array}$ & .063 & .059 & .002 & 1.141 & -.053 & .179 \\
\hline & P-self & .010 & .027 & .000 & .149 & -.042 & .062 \\
\hline & P-others & -.006 & .027 & .000 & .042 & -.059 & .048 \\
\hline & P-situations & .058 & .025 & .009 & 5.339 & .009 & .108 \\
\hline & $\begin{array}{l}\text { Reduction of unforgiveness } \\
(\mathrm{N} \text {-scale })\end{array}$ & -.074 & .077 & .001 & .911 & -.225 & .078 \\
\hline & N-self & -.035 & .038 & .001 & .845 & -.108 & .039 \\
\hline & $\mathrm{N}$-others & -.044 & .032 & .003 & 1.874 & -.107 & .019 \\
\hline & $\mathrm{N}$-situations & .005 & .030 & .000 & .026 & -.054 & .064 \\
\hline \multirow[t]{9}{*}{ Anxiety } & Total forgiveness & .187 & .108 & .004 & 2.997 & -.025 & .399 \\
\hline & $\begin{array}{l}\text { Positive forgiveness } \\
\text { (P-scale) }\end{array}$ & .105 & .069 & .004 & 2.306 & -.031 & .240 \\
\hline & P-self & .017 & .031 & .001 & .287 & -.044 & .078 \\
\hline & P-others & .036 & .032 & .002 & 1.297 & -.026 & .098 \\
\hline & P-situations & .052 & .029 & .005 & 3.147 & -.006 & .109 \\
\hline & $\begin{array}{l}\text { Reduction of unforgiveness } \\
(\mathrm{N} \text {-scale })\end{array}$ & .082 & .086 & .001 & .916 & -.087 & .251 \\
\hline & $\mathrm{N}$-self & .000 & .042 & .000 & .000 & -.083 & .083 \\
\hline & N-others & .005 & .037 & .000 & .018 & -.068 & .078 \\
\hline & $\mathrm{N}$-situations & .077 & .034 & .006 & 5.201 & .011 & .144 \\
\hline
\end{tabular}


Table 3 (continued)

\begin{tabular}{|c|c|c|c|c|c|c|c|}
\hline \multicolumn{2}{|l|}{ Moderating role of gender } & \multicolumn{6}{|c|}{ Indirect effects } \\
\hline Predictors & Outcomes & $B$ & $S E$ & $\Delta R 2$ & $F$ & LLCI & ULCI \\
\hline \multirow{9}{*}{$\begin{array}{l}\text { Emotional control - total } \\
\text { score }\end{array}$} & Total forgiveness & .244 & .113 & .007 & 4.634 & .021 & .466 \\
\hline & $\begin{array}{l}\text { Positive forgiveness } \\
\text { (P-scale) }\end{array}$ & .081 & .065 & .003 & 1.569 & -.046 & .209 \\
\hline & P-self & -.004 & .029 & .000 & .020 & -.061 & .053 \\
\hline & P-others & .039 & .029 & .003 & 1.746 & -.019 & .097 \\
\hline & P-situations & .047 & .027 & .005 & 2.919 & -.007 & .100 \\
\hline & $\begin{array}{l}\text { Reduction of unforgiveness } \\
\text { (N-scale) }\end{array}$ & .162 & .088 & .005 & 3.420 & -.010 & .335 \\
\hline & $\mathrm{N}$-self & .063 & .042 & .004 & 2.291 & -.019 & .144 \\
\hline & N-others & .013 & .034 & .000 & .145 & -.054 & .081 \\
\hline & N-situations & .087 & .036 & .009 & 5.947 & .017 & .156 \\
\hline \multirow[t]{9}{*}{ Control of anger } & Total forgiveness & .293 & .254 & .002 & 1.333 & -.206 & .792 \\
\hline & $\begin{array}{l}\text { Positive forgiveness } \\
\text { (P-scale) }\end{array}$ & .109 & .146 & .001 & .557 & -.178 & .395 \\
\hline & P-self & .016 & .065 & .000 & .057 & -.112 & .143 \\
\hline & P-others & .016 & .066 & .000 & .059 & -.114 & .146 \\
\hline & P-situations & .077 & .061 & .003 & 1.588 & -.043 & .198 \\
\hline & $\begin{array}{l}\text { Reduction of unforgiveness } \\
\text { (N-scale) }\end{array}$ & .184 & .195 & .002 & .891 & -.199 & .568 \\
\hline & $\mathrm{N}$-self & .018 & .092 & .000 & .037 & -.163 & .198 \\
\hline & N-others & .007 & .077 & .000 & .008 & -.145 & .159 \\
\hline & N-situations & .161 & .079 & .006 & 4.130 & .005 & .317 \\
\hline \multirow[t]{9}{*}{ Control of depression } & Total forgiveness & .208 & .287 & .001 & .526 & -.355 & .770 \\
\hline & $\begin{array}{l}\text { Positive forgiveness } \\
\text { (P-scale) }\end{array}$ & .101 & .166 & .001 & .368 & -.226 & .427 \\
\hline & P-self & -.055 & .074 & .001 & .557 & -.201 & .090 \\
\hline & P-others & .055 & .075 & .001 & .538 & -.093 & .203 \\
\hline & P-situations & .101 & .0702 & .003 & 2.091 & -.036 & .238 \\
\hline & $\begin{array}{l}\text { Reduction of unforgiveness } \\
\text { (N-scale) }\end{array}$ & .107 & .222 & .000 & .233 & -.329 & .543 \\
\hline & $\mathrm{N}$-self & .077 & .105 & .001 & .539 & -.129 & .284 \\
\hline & N-others & -.033 & .088 & .000 & .141 & -.205 & .139 \\
\hline & N-situations & .063 & .090 & .001 & .494 & -.114 & .241 \\
\hline
\end{tabular}


Table 3 (continued)

\begin{tabular}{|c|c|c|c|c|c|c|c|}
\hline \multicolumn{2}{|c|}{ Moderating role of gender } & \multicolumn{6}{|c|}{ Indirect effects } \\
\hline Predictors & Outcomes & $B$ & $S E$ & $\Delta R 2$ & $F$ & LLCI & ULCI \\
\hline \multirow[t]{9}{*}{ Control of anxiety } & Total forgiveness & .787 & .257 & .015 & 9.343 & .281 & 1.292 \\
\hline & $\begin{array}{l}\text { Positive forgiveness } \\
\text { (P-scale) }\end{array}$ & .225 & .146 & .004 & 2.365 & -.062 & .512 \\
\hline & P-self & .004 & .065 & .000 & .004 & -.124 & .132 \\
\hline & P-others & .140 & .066 & .007 & 4.521 & -.011 & .270 \\
\hline & P-situations & .081 & .062 & .003 & 1.713 & -.040 & .201 \\
\hline & $\begin{array}{l}\text { Reduction of unforgiveness } \\
\text { (N-scale) }\end{array}$ & .562 & .201 & .013 & 7.827 & .168 & .957 \\
\hline & $\mathrm{N}$-self & .230 & .094 & .010 & 5.973 & .045 & .415 \\
\hline & N-others & .086 & .078 & .002 & 1.231 & -.066 & .239 \\
\hline & $\mathrm{N}$-situations & .246 & .082 & .014 & 8.966 & .085 & .407 \\
\hline
\end{tabular}

As shown in Table 2, women's negative affect and anxiety were negatively correlated with multiple dimensions of dispositional forgiveness, whereas positive affect was positively associated with all facets of forgivingness. Women's control of emotions, including control of anger and depression, was inversely related to total forgiveness and reduced unforgiveness, but not related to positive forgiveness. Control of anxiety was negatively associated with overcoming unforgiveness of situations beyond control.

In the case of male participants, negative affect and anxiety were inversely correlated with overall forgiveness and all facets of reducing unforgiveness. Positive affect was positively related to total and positive forgiveness (especially of situations and others). Control of anger was negatively correlated with overcoming unforgiveness of self; control of depression was negatively associated with general forgivingness and decreased unforgiveness, particularly of situations. Finally, control of anxiety was positively associated with total forgiveness and reduction of unforgiveness (general, as well as of oneself and situations).

Next, we examined the moderating role of gender in the relationship between affective traits and disposition to forgive. Sixty-three models adopting subsequent affective traits as predictors and facets of forgivingness as outcomes were tested, and eight of them confirmed the moderating role of respondents' gender. Table 3 presents interaction effects of the examined models. ${ }^{1}$

The analysis revealed no significant interaction effect of positive affect and gender on any dimension of forgiveness, but confirmed a significant effect of negative

\footnotetext{
${ }^{1}$ As age is one of the key sociodemographic predictors of forgiveness (Cheng \& Yim, 2008; Kaleta \& Mróz, 2018), we alternatively tested each of the models after including participants' age as a covariate. Although age was a significant covariate in majority models, the findings were essentially the same as reported here.
} 
affect and gender in relation to positive forgiveness of situations (Table 3). It showed that negative affect was negatively related to this type of forgiveness for women $(B=-0.046, S E=0.011, \mathrm{CI} 95 \%=[-0.067,-0.025])$, but not for men $(B=0.012$, $S E=0.023$, CI95\% $=[-0.033,0.057])$. Also, the link between anxiety and reduced unforgiveness of situations was more negative for females $(B=-0.24, S E=0.02$, $\mathrm{CI} 95 \%=[-0.275,-0.211])$ when compared to males $(B=-0.17, \quad S E=0.03$, $\mathrm{CI} 95 \%=[-0.224,-0.108])$. Overall emotional control was negatively associated with total forgivingness in female $(B=-0.24, S E=0.05$, CI95\% $=[-0.340,-0.141])$, but not in male respondents $(B=0.003, S E=0.10,195 \%=[-0.195,0.202])$. Similarly, overall emotional control was negatively related to reduced unforgiveness of situations in females $(B=-0.10, S E=0.02, \mathrm{CI} 95 \%=[-0.135,-0.072])$ and not in males $(B=-0.02, S E=0.03, \mathrm{CI} 95 \%=[-0.079,0.045])$. Control of anger was negatively associated with reduced unforgiveness of situations for females $(B=-0.25, S E=0.04$, $\mathrm{CI} 95 \%=[-0.329,-0.185])$, while the link was nonsignificant for males $(\beta=-0.10$, $S E=0.07, \mathrm{CI} 95 \%=[-0.235,0.042])$. In contrast, in men greater control of anxiety was linked to higher total forgivingness $(B=0.61, S E=0.22$, CI95\% $=[0.178,1.046])$, reduced unforgiveness $(B=0.46, S E=0.17, \mathrm{CI} 95 \%=[0.122,0.801])$, and reduced unforgiveness of self $(B=0.23, S E=0.09, \mathrm{CI} 95 \%=[0.081,0.399])$ and in women it was not significantly related to these facets of forgiveness (respectively, $B=-0.17$, $S E=0.13$, CI95\% $=[-0.434,0.083], B=-0.10, S E=0.10$, CI95\% $=[-0.302,0.101]$, $B=0.01, S E=0.05, \mathrm{CI} 95 \%=[-0.085,0.104])$. The relationship between control of anxiety and reduced unforgiveness of situations was positive for males $(B=0.16$, $S E=0.07, \mathrm{CI} 95 \%=[0.019,0.296])$, while for females it was negative $(B=-0.09$, $S E=0.04$, CI95\% $=[-0.171,-0.006])$. Gender did not moderate the effect of control of depression on any dimension of forgivingness.

Thus, moderation analysis confirmed gender differences in processing forgiveness of self and of situations. Higher negative affect, anxiety, emotional control, including control of anger and of anxiety, made overcoming negative responses in situations beyond control more difficult for females than for males. In contrast, greater control of anxiety helped males to be more forgiving, especially toward themselves and situations. The moderating role of gender in relation to forgivingness of others did not occur.

\section{Discussion}

Although neglected by most researchers, gender-related differences in forgivingness (and the associated variables) should be given more empirical attention. It is significant not only to gain more insight into the forgiveness phenomenon, but also to apply effective interventions and therapeutic techniques. Our study attempts to fill in this gap as it was aimed at direct comparison of men and women in their disposition to forgive and the way it is linked to affective traits.

The first hypothesis about a stronger tendency to forgive among women was not supported. Women revealed lower forgiveness in the total score and in its negative dimension. Few studies showed a similar trend, four of which included dispositional forgiveness (Brown, 2003; Charzyńska, 2015; Exline et al., 2004; Piątek, 2011). 
Two other studies were focused on forgiveness of a specific offense in close relationships, showing male partners to be more forgiving toward female partners (Finkel et al., 2002; Miller \& Worthington, 2010). However, they all measured forgiveness of others, while our results demonstrated that women are less able to overcome unforgiveness toward themselves and situations, but not toward other people. Also, there were no significant differences between women and men in positive facets of forgiveness. Multidimensional measures we used might have helped us investigate gender differences more accurately. To our knowledge, our study is the first to examine gender differences in terms of that many aspects of forgivingness.

Females' lower disposition to reduce unforgiveness, especially toward self and situations beyond control, might be interpreted as a function of different self-construals. An interdependent view of the self characterizes females as focused on maintaining connection to people and being less separated from the social context (Markus \& Kitayama, 1991). Their own failures and wrongdoings might be seen as disturbing the harmony with relevant others and threatening their positive self-portrait (Fincham et al., 2004). Consequently, an interdependent self-construal makes females prone to feel shame (Markus \& Kitayama, 1991) which is negatively related to forgiveness, especially of self (Hall \& Fincham, 2005).

Consistently with previous studies (e.g., Rye et al., 2001; Thompson et al., 2005; Uysal \& Satici, 2014), we found that negative affect, anxiety, control of anger, and of depression were negatively correlated with forgivingness, while positive affect was positively related to forgiveness, in both women and men. Gender significantly moderated a number of the relationships between affective traits and forgivingness, especially links involving emotional control. Few previous studies also demonstrated genderbased correlations between different variables and forgiveness. For instance, both Fincham et al. (2002) and Toussaint and Webb (2005) found that empathy is more strongly associated with forgiveness in men than in women. Fincham et al. (2002) also showed that the direct effect of attribution of responsibility on marital forgiveness proved to be stronger for wives than for husbands. Fincham et al. (2004) demonstrated that partner reports of inefficient conflict resolution were positively correlated with retaliation, a negative dimension of marital forgiveness, for husbands only.

We found - in contrast to our hypotheses - negative relationships between negative affect, anxiety, emotional control, including control of anger and of anxiety, and willingness to forgive of situations stronger for female than for male participants. For interdependent individuals, it is important to control intense experiences of negative emotions, especially anger, because it threatens their selves (Markus \& Kitayama, 1991). However, in the light of our findings strong emotional control makes forgiving difficult for women. In turn, control of anxiety was positively related to forgiveness in men. For independent selves, it is important to express self and egofocused emotions, such as anger or frustration. Controlling anxiety in men might foster such expression and, consequently, favor forgiveness. Our results suggest that women and men need different interventions in facilitating forgiveness (Miller \& Worthington, 2015). Females need more self-forgiveness interventions, releasing anxiety and promoting more open expression of negative emotions in the way they are able to accept, for instance in constructive communication. Males need work on emotion regulation, especially controlling of anxiety and of anger. 


\section{Limitations of the Study}

Although the present study attempts to fill in the gap by addressing the scarcely examined question of gender differences in forgiveness, it is burdened with a number of limitations. First, there is a significant gender imbalance in the sample. It is a common problem that women tend to participate in forgiveness studies more often than men (Root \& Exline, 2011; Worthington et al., 2000). We collected data only from interested individuals who were willing to participate in the study completely voluntarily (for no remuneration). The question is whether some bonuses would encourage more men to participate in the research and help minimize the imbalance. Secondly, the design of the research is cross-sectional and the statistics are merely correlational and cannot be used to draw conclusions about causality. Longitudinal studies would be more useful in exploring the causal relationships between analyzed variables more extensively. Thirdly, we did not control some important variables, such as social desirability bias which is related to forgiveness and which may moderate the link between affective traits and forgivingness (e.g., Rye et al., 2001). Finally, because the study uses measures of dispositional forgiveness, it does not in fact address actual forgiving. Consequently, the findings cannot be extended to forgiveness occurring in natural situations. Ability to forgive is just one of many more predictors of episodic forgiveness that is, in fact, more strongly related to contextual circumstances, such as severity of the wrongdoing, apology, relational closeness, and passage of time (Boon \& Sulsky, 1997; Johnson et al., 2013; Koutsos et al., 2008). Thus, our findings still do not make it possible to predict whether women or men would be more willing to forgive a particular offense in a given context. Future research should apply more complex models in which both disposition to forgive and gender would mediate and moderate the relationships between different contextual factors, episodic forgiveness, and related variables. For instance, the relationship between apology and actual forgiveness could be mediated by forgivingness and moderated by gender.

Open Access This article is licensed under a Creative Commons Attribution 4.0 International License, which permits use, sharing, adaptation, distribution and reproduction in any medium or format, as long as you give appropriate credit to the original author(s) and the source, provide a link to the Creative Commons licence, and indicate if changes were made. The images or other third party material in this article are included in the article's Creative Commons licence, unless indicated otherwise in a credit line to the material. If material is not included in the article's Creative Commons licence and your intended use is not permitted by statutory regulation or exceeds the permitted use, you will need to obtain permission directly from the copyright holder. To view a copy of this licence, visit http://creativecommons.org/licen ses/by/4.0/.

\section{References}

Agerström, J., Möller, K., \& Archer, T. (2006). Moral reasoning: The influence of affective personality, dilemma content and gender. Social Behavior and Personality, 34, 1259-1276. https://doi.org/10. 2224/sbp.2006.34.10.1259 
Allemand, M. (2008). Age differences in forgivingness: The role of future time perspective. Journal of Research in Personality, 42, 1137-1147. https://doi.org/10.1016/j.jrp.2008.02.009

Baker, J. C., Williams, J. K., Witvliet, C. V. O., \& Hill, P. C. (2017). Positive reappraisals after an offense: Event-related potentials and emotional effects of benefit-finding and compassion. The Journal of Positive Psychology, 12, 373-384. https://doi.org/10.1080/17439760.2016.1209540

Barcaccia, B., Salvati, M., Pallini, S., Saliani, A. M., Baiocco, R., \& Vecchio, G. M. (2020). The bitter taste of revenge: Negative affect, depression and anxiety. Current Psychology. https://doi.org/10. 1007/s12144-020-00643-1

Baumeister, R. F., Exline, J. J., \& Sommer, K. L. (1998). The victim role, grudge theory, and two dimensions of forgiveness. In E. L. Worthington (Ed.), Dimensions of forgiveness: Psychological research and theological perspectives (pp. 79-104). Templeton Foundation Press.

Berry, J. W., Worthington, E. L., Jr., Parrott, L., III., O'Connor, L. E., \& Wade, N. G. (2001). Dispositional forgivingness: Development and construct validity of the transgression narrative test of forgivingness (TNTF). Personality and Social Psychology Bulletin, 27, 1277-1290. https://doi.org/10. $1177 / 01461672012710004$

Berry, J. W., Worthington, E. L., O'Connor, L. E., Parrott, L., \& Wade, N. G. (2005). Forgivingness, vengeful rumination, and affective traits. Journal of Personality, 73, 183-226. https://doi.org/10. $1111 / \mathrm{j} .1467-6494.2004 .00308 . x$

Boon, S. D., \& Sulsky, L. M. (1997). Attributions of blame and forgiveness in romantic relationships: A policy-capturing study. Journal of Social Behavior and Personality, 12, 19-44.

Brose, L. A., Rye, M. S., Lutz-Zois, C., \& Ross, S. R. (2005). Forgiveness and personality traits. Personality and Individual Differences, 39, 35-46. https://doi.org/10.1016/j.paid.2004.11.001

Brown, R. P. (2003). Measuring individual differences in the tendency to forgive: Construct validity and links with depression. Personality and Social Psychology Bulletin, 29, 759-771. https://doi.org/10. $1177 / 0146167203029006008$

Brown, R. P. (2004). Vengeance is mine: Narcissism, vengeance, and the tendency to forgive. Journal of Research in Personality, 38, 576-584. https://doi.org/10.1016/j.jrp.2003.10.003

Brown, R. P., Barnes, C. D., \& Campbell, N. J. (2007). Fundamentalism and forgiveness. Personality and Individual Differences, 43, 1437-1447. https://doi.org/10.1016/j.paid.2007.04.025

Brzozowski, P. (2010). Skala uczuć pozytywnych i negatywnych SUPIN. Polska adaptacja PANAS Davida Watsona i Lee Anny Clark. Podręcznik [Scale of positive and negative affects SUPIN: Polish adaptation of PANAS by David Watson \& Anna Clark]. Warsaw: PTP.

Burnette, J. L., Davis, D. E., Green, J. D., Worthington, E. L., Jr., \& Bradfield, E. (2009). Insecure attachment and depressive symptoms: The mediating role of rumination, empathy, and forgiveness. Personality and Individual Differences, 46, 276-280. https://doi.org/10.1016/j.paid.2008.10.016

Charzyńska, E. (2015). Sex differences in spiritual coping, forgiveness, and gratitude before and after a basic alcohol addiction treatment program. Journal of Religion and Health, 54(5), 1931-1949. https://doi.org/10.1007/s10943-015-0002-0

Cheng, S. T., \& Yim, Y. K. (2008). Age differences in forgiveness: The role of future time perspective. Psychology of Aging, 23, 676-680. https://doi.org/10.1037/0882-7974.23.3.676

Chung, M. S. (2014). Pathways between attachment and marital satisfaction: The mediating roles of rumination, empathy, and forgiveness. Personality and Individual Differences, 70, 246-251. https:// doi.org/10.1016/j.paid.2014.06.032

Cohen, A. B., Malka, A., Rozin, P., \& Cherfas, L. (2006). Religion and unforgivable offenses. Journal of Personality, 74, 85-118. https://doi.org/10.1111/j.1467-6494.2005.00370.x

Cross, S. E., \& Madson, L. (1997). Models of the self: Self-construals and gender. Psychological Bulletin, 122, 5-37.

DiBlasio, F. A. (1998). The use of a decision-based forgiveness intervention within intergenerational family therapy. Journal of Family Therapy, 20, 77-96. https://doi.org/10.1111/1467-6427.00069

Eaton, J., Struthers, C. W., \& Santelli, A. G. (2006). Dispositional and state forgiveness: The role of selfesteem, need for structure, and narcissism. Personality and Individual Differences, 41, 371-380. https://doi.org/10.1016/j.paid.2006.02.005

Edwards, L. M., Lapp-Rincker, R. H., Magyar-Moe, J. L., Rehfeldt, J. D., Ryder, J. A., Brown, J. C., \& Lopez, S. J. (2002). A positive relationship between religious faith and forgiveness: Faith in the absence of data? Pastoral Psychology, 50, 147-152. https://doi.org/10.1023/A:1012940402668

Enright, R. D. (1996). Counseling within the forgiveness triad: On forgiving, receiving forgiveness, and self-forgiveness. Counseling and Values, 40, 107-126. https://doi.org/10.1002/j.2161-007X.1996. tb00844.x 
Enright, R. D., \& Fitzgibbons, R. P. (2000). Helping clients forgive: An empirical guide for resolving anger and restoring hope. American Psychological Association.

Exline, J. J., Baumeister, R. F., Bushman, B. J., Campbell, W. K., \& Finkel, E. J. (2004). Too proud to let go: Narcissistic entitlement as a barrier to forgiveness. Journal of Personality and Social Psychology, 87, 894-912. https://doi.org/10.1037/0022-3514.87.6.894

Fatfouta, R., Gerlach, T. M., Schröder-Abé, M., \& Merkl, A. (2015). Narcissism and lack of interpersonal forgiveness: The mediating role of state anger, state rumination, and state empathy. Personality and Individual Differences, 75, 36-40. https://doi.org/10.1016/j.paid.2014.10.051

Fehr, R., Gelfand, M. J., \& Nag, M. (2010). The road to forgiveness: A meta-analytic synthesis of its situational and dispositional correlates. Psychological Bulletin, 136, 894-914. https://doi.org/10.1037/ a0019993

Fincham, F. D., Beach, S. R., \& Davila, J. (2004). Forgiveness and conflict resolution in marriage. Journal of Family Psychology, 18, 72-81. https://doi.org/10.1037/0893-3200.18.1.72

Fincham, F. D., Paleari, F. G., \& Regalia, C. (2002). Forgiveness in marriage: The role of relationship quality, attributions, and empathy. Personal Relationships, 9, 27-37. https://doi.org/10.1111/14756811.00002

Finkel, E. J., Rusbult, C. E., Kumashiro, M., \& Hannon, P. A. (2002). Dealing with betrayal in close relationships: Does commitment promote forgiveness? Journal of Personality and Social Psychology, 82, 956-974. https://doi.org/10.1037/0022-3514.82.6.956

Flanigan, B. (1992). Forgiving the unforgivable. Macmillan.

Fujita, F., Diener, E., \& Sandvik, E. (1991). Gender differences in negative affect and well-being: The case for emotional intensity. Journal of Personality and Social Psychology, 61, 427-434. https://doi. org/10.1037//0022-3514.61.3.427

Giammarco, E. A., \& Vernon, P. A. (2014). Vengeance and the dark triad: The role of empathy and perspective taking in trait forgivingness. Personality and Individual Differences, 67, 23-29. https://doi. org/10.1016/j.paid.2014.02.010

Gordon, K. C., \& Baucom, D. H. (1998). Understanding betrayals in marriage: A synthesized model of forgiveness. Family Process, 37, 425-450. https://doi.org/10.1111/j.1545-5300.1998.00425.x

Gordon, K. C., Baucom, D. H., \& Snyder, D. K. (2005). Forgiveness in couples: Divorce, infidelity, and couples therapy. In E. Worthington (Ed.), Handbook of forgiveness (pp. 407-421). Brunner-Routledge.

Gross, J. J. (1998). The emerging field of emotion regulation: An integrative review. Review of General Psychology, 2, 271-299. https://doi.org/10.1037/1089-2680.2.3.271

Gross, J. J., \& John, O. P. (2003). Individual differences in two emotion regulation processes: Implications for affect, relationships, and well-being. Journal of Personality and Social Psychology, 85, 348-362. https://doi.org/10.1037/0022-3514.85.2.348

Hall, J. H., \& Fincham, F. D. (2008). The temporal course of self-forgiveness. Journal of Social and Clinical Psychology, 27, 174-202. https://doi.org/10.1521/jscp.2008.27.2.174

Hayes, A. F. (2018). Introduction to mediation, moderation, and conditional process analysis: A regression-based approach. The Guilford Press.

Hill, P. L., \& Allemand, M. (2010). Forgivingness and adult patterns of individual differences in environmental mastery and personal growth. Journal of Research in Personality, 44, 245-250. https://doi. org/10.1016/j.jrp.2010.01.006

Hodgson, L. K., \& Wertheim, E. H. (2007). Does good emotion management aid forgiving? Multiple dimensions of empathy, emotion management and forgiveness of self and others. Journal of Social and Personal Relationships, 24, 931-949. https://doi.org/10.1177/0265407507084191

Johnson, H. D., Wernli, M. A., \& LaVoie, J. C. (2013). Situational, interpersonal, and intrapersonal characteristic associations with adolescent conflict forgiveness. The Journal of Genetic Psychology, 174, 291-315. https://doi.org/10.1080/00221325.2012.670672

Juczyński, Z. (2012). Narzędzia pomiaru w promocji i psychologii zdrowia [Measuring tool in promotion and health psychology]. Warsaw: PTP.

Kaleta, K., \& Mróz, J. (2018). Forgiveness and life satisfaction across different age groups in adults. Personality and Individual Differences, 120, 17-23. https://doi.org/10.1016/j.paid.2017.08.008

Kaleta, K., Mróz, J., \& Guzewicz, M. (2016). Polska adaptacja Skali Przebaczenia - Heartland Forgiveness Scale [Polish adaptation of the Heartland Forgiveness Scale]. Przeglad Psychologiczny, 59, $387-402$.

Kamat, V. I., Jones, W. H., \& Lawler-Row, K. A. (2006). Assessing forgiveness as a dimension of personality. Individual Differences Research, 4, 322-330. https://doi.org/10.3200/JRLP.143.2.175-192 
Koch, K., Pauly, K., Kellermann, T., Seiferth, N. Y., Reske, M., Backes, V., \& Schneider, F. (2007). Gender differences in the cognitive control of emotion: An fMRI study. Neuropsychologia, 45, 27442754. https://doi.org/10.1016/j.neuropsychologia.2007.04.012

Koutsos, P., Wertheim, E. H., \& Kornblum, J. (2008). Paths to interpersonal forgiveness: The roles of personality, disposition to forgive and contextual factors in predicting forgiveness following a specific offence. Personality and Individual Differences, 44, 337-348. https://doi.org/10.1016/j.paid. 2007.08.011

Lawler-Row, K. A., \& Piferi, R. L. (2006). The forgiving personality: Describing a life well lived? Personality and Individual Differences, 41, 1009-1020. https://doi.org/10.1016/j.paid.2006.04.007

Macaskill, A. (2012). Differentiating dispositional self- forgiveness from other-forgiveness: Associations with mental health and life satisfaction. Journal of Social and Clinical Psychology, 31, 28-50. https://doi.org/10.1521/jscp.2012.31.1.28

Maltby, J., Day, L., \& Barber, L. (2004). Forgiveness and mental health variables: Interpreting the relationship using an adaptational-continuum model of personality and coping. Personality and Individual Differences, 37, 1629-1641. https://doi.org/10.1016/j.paid.2004.02.017

Mami, S., Gholami, M., \& Ahmadi, V. (2019). Investigating the simple and multiple correlation of emotional regulation with marital forgiveness and family efficacy in married female students of Islamic Azad University of Ilam. Journal of Basic Research in Medical Sciences, 6, 29-36.

Markus, H., \& Kitayama, S. (1991). Culture and the self: Implications for cognition, emotion, and motivation. Psychological Review, 98, 224-253.

Matud, M. P. (2004). Gender differences in stress and coping styles. Personality and Individual Differences, 37, 1401-1415. https://doi.org/10.1016/j.paid.2004.01.010

McCullough, M. E., Bellah, C. G., Kilpatrick, S. D., \& Johnson, J. L. (2001). Vengefulness: Relationships with forgiveness, rumination, well-being, and the big five. Personality and Social Psychology Bulletin, 27, 601-610. https://doi.org/10.1177/0146167201275008

McCullough, M. E., Emmons, R. A., \& Tsang, J. A. (2002). The grateful disposition: A conceptual and empirical topography. Journal of Personality and Social Psychology, 82, 112-127. https://doi.org/ 10.1037//0022-3514.82.1.112

McCullough, M. E., Rachal, K. C., Sandage, S. J., Worthington, E. L., Jr., Brown, S. W., \& Hight, T. L. (1998). Interpersonal forgiving in close relationships: II. Theoretical elaboration and measurement. Journal of Personality and Social Psychology, 75, 1586-1603. https://doi.org/10.1037/0022-3514. 75.6.1586

McCullough, M. E., Worthington, E. L., \& Rachal, K. C. (1997). Interpersonal forgiving in close relationships. Journal of Personality and Social Psychology, 73, 321-336. https://doi.org/10.1037/00223514.73.2.321

McRae, K., Ochsner, K. N., Mauss, I. B., Gabrieli, J. J., \& Gross, J. J. (2008). Gender differences in emotion regulation: An fMRI study of cognitive reappraisal. Group Processes \& Intergroup Relations, 11, 143-162. https://doi.org/10.1177/1368430207088035

Miller, A. J., Worthington, E. L., Jr., \& McDaniel, M. A. (2008). Gender and forgiveness: A meta-analytic review and research agenda. Journal of Social and Clinical Psychology, 27, 843-876. https:// doi.org/10.1521/jscp.2008.27.8.843

Miller, A. J., \& Worthington, E. L., Jr. (2010). Sex differences in forgiveness and mental health in recently married couples. The Journal of Positive Psychology, 5, 12-23. https://doi.org/10.1080/ 17439760903271140

Miller, A. J., \& Worthington, E. L. (2015). Sex, forgiveness, and health. In L. L. Toussaint, E. L. Worthington, \& D. R. Williams (Eds.), Forgiveness and health (pp. 173-187). Springer.

Mróz, J., \& Kaleta, K. (2017). Cognitive and emotional predictors of episodic and dispositional forgiveness. Polish Psychological Bulletin, 48, 143-153. https://doi.org/10.1515/ppb-2017-0018

Mullet, E., Houdbine, A., Laumonier, S., \& Girard, M. (1998). "Forgivingness": Factor structure in a sample of young, middle-aged, and elderly adults. European Psychologist, 3, 289-297. https://doi. org/10.1027/1016-9040.3.4.289

Neto, F., \& Mullet, E. (2004). Personality, self-esteem, and self-construal as correlates of forgivingness. European Journal of Personality, 18, 15-30. https://doi.org/10.1002/per.500

Parker, G., \& Brotchie, H. (2010). Gender differences in depression. International Review of Psychiatry, 22, 429-436. https://doi.org/10.3109/09540261.2010.492391

Piątek, M. (2011). Przebaczenie w doświadczeniu życiowym kobiet i mężczyzn [Forgiveness in the life experience of women and men]. Nowiny Lekarskie, 80, 317-322.

Roberts, R. C. (1995). Forgivingness. American Philosophical Quarterly, 32, 289-306. 
Root, B. L., \& Exline, J. J. (2011). Gender differences in response to experimental forgiveness prompts: Do men show stronger responses than women? Basic and Applied Social Psychology, 33, 182-193. https://doi.org/10.1080/01973533.2011.568850

Ryan, R. B., \& Kumar, V. K. (2005). Willingness to forgive: Relationships with mood, anxiety and severity of symptoms. Mental Health, Religion \& Culture, 8, 13-16. https://doi.org/10.1080/1367467041 0001666543

Rye, M. S., Loiacono, D. M., Folck, C. D., Olszewski, B. T., Heim, T. A., \& Madia, B. P. (2001). Evaluation of the psychometric properties of two forgiveness scales. Current Psychology, 20, 260-277. https://doi.org/10.1007/s12144-001-1011-6

Rye, M. S., \& Pargament, K. I. (2002). Forgiveness and romantic relationships in college: Can it heal the wounded heart? Journal of Clinical Psychology, 58, 419-441. https://doi.org/10.1002/jclp.1153

Sells, J. N., \& Hargrave, T. D. (1998). Forgiveness: A review of the theoretical and empirical literature. Journal of Family Therapy, 20, 21-36.

Spielberger, C. D., Gorsuch, R. L., Lushene, R., Vagg, P. R., \& Jacobs, G. A. (1983). Manual for the state-trait anxiety inventory. Consulting Psychologists Press.

Subkoviak, M. J., Enright, R. D., Wu, C. R., Gassin, E. A., Freedman, S., Olson, L. M., et al. (1995). Measuring interpersonal forgiveness in late adolescence and middle adulthood. Journal of Adolescence, 18, 641-655. https://doi.org/10.1006/jado.1995.1045

Thompson, L. Y., \& Synder, C. R. (2003). Measuring forgiveness. In S. J. Lopez \& C. R. Snyder (Eds.), Positive psychological assessment: A handbook of models and measures (pp. 301-312). APA.

Thompson, L. Y., Snyder, C. R., Hoffman, L., Michael, S. T., Rasmussen, H. N., Billings, L. S., Heinze, L., Neufeld, J. E., Shorey, H. S., Roberts, J. C., \& Roberts, D. E. (2005). Dispositional forgiveness of self, others, and situations. Journal of Personality, 73, 313-359. https://doi.org/10.1111/j.14676494.2005.00311.x

Thomsen, D. K., Mehlsen, M. Y., Viidik, A., Sommerlund, B., \& Zachariae, R. (2005). Age and gender differences in negative affect-Is there a role for emotion regulation? Personality and Individual Differences, 38, 1935-1946. https://doi.org/10.1016/j.paid.2004.12.001

Toussaint, L., \& Friedman, P. (2009). Forgiveness, gratitude, and well-being: The mediating role of affect and beliefs. Journal of Happiness Studies, 10, 635-654. https://doi.org/10.1007/s10902-008-9111-8

Toussaint, L., \& Webb, J. R. (2005). Gender differences in the relationship between empathy and forgiveness. The Journal of Social Psychology, 145, 673-685. https://doi.org/10.3200/SOCP.145.6.673-686

Toussaint, L. L., Williams, D. R., Musick, M. A., \& Everson-Rose, S. A. (2008). The association of forgiveness and 12-month prevalence of major depressive episode: Gender differences in a probability sample of US adults. Mental Health, Religion and Culture, 11, 485-500. https://doi.org/10.1080/ 13674670701564989

Uysal, R., \& Satici, S. A. (2014). The mediating and moderating role of subjective happiness in the relationship between vengeance and forgiveness. Educational Sciences: Theory and Practice, 14, 20972105. https://doi.org/10.12738/estp.2014.6.2207

Wade, N. G., \& Worthington, E. L. (2003). Overcoming interpersonal offenses: Is forgiveness the only way to deal with unforgiveness? Journal of Counseling and Development, 81, 343-353. https://doi. org/10.1002/j.1556-6678.2003.tb00261.x

Watson, D., Clark, L. A., \& Tellegen, A. (1988). Development and validation of brief measures of positive and negative affect: The PANAS scales. Journal of Personality and Social Psychology, 54, 1063-1070.

Watson, M., \& Greer, S. (1983). Development of a questionnaire measure of emotional control. Journal of Psychosomatic Research, 27, 299-305.

Witvliet, C. V. O., DeYoung, N., Hofelich, A., \& DeYoung, P. (2011). Compassionate reappraisal and emotion suppression as alternatives to offense-focused rumination: Implications for forgiveness and psychophysiological well-being. The Journal of Positive Psychology, 6, 286-299. https://doi.org/10. 1080/17439760.2011.577091

Witvliet, C. V. O., Hofelich Mohr, A. J., Hinman, N. G., \& Knoll, R. W. (2015). Transforming or restraining rumination: The impact of compassionate reappraisal versus emotion suppression on empathy, forgiveness, and affective psychophysiology. The Journal of Positive Psychology, 10, 248-261. https://doi.org/10.1080/17439760.2014.941381

Witvliet, C. V. O., Knoll, R. W., Hinman, N. G., \& DeYoung, P. A. (2010). Compassion-focused reappraisal, benefit-focused reappraisal, and rumination after an interpersonal offense: Emotion-regulation implications for subjective emotion, linguistic responses, and physiology. The Journal of Positive Psychology, 5, 226-242. https://doi.org/10.1080/17439761003790997 
Worthington, E. L., Rueger, S. Y., Davis, E. B., \& Wortham, J. (2019). "Mere” Christian forgiveness: An ecumenical Christian conceptualization of forgiveness through the lens of stress-and-coping theory. Religions, 10(1), 44-59. https://doi.org/10.3390/rel10010044

Worthington, E. L., Sandage, S. J., \& Berry, J. W. (2000). Group interventions to promote forgiveness. In M. E. McCullough, K. I. Pargament, \& C. E. Thoresen (Eds.), Forgiveness: Theory, research, and practice (pp. 228-253). Guilford Press.

Worthington, E. L., \& Scherer, M. (2004). Forgiveness is an emotion-focused coping strategy that can reduce health risks and promote health resilience: Theory, review, and hypotheses. Psychology \& Health, 19, 385-405. https://doi.org/10.1080/0887044042000196674

Worthington, E. L., \& Wade, N. G. (1999). The psychology of unforgiveness and forgiveness and implications for clinical practice. Journal of Social and Clinical Psychology, 18, 385-418. https://doi.org/ 10.1521/jscp.1999.18.4.385

Wrześniewski, K., Sosnowski, T., \& Matusik, D. (2002). Inwentarz Stanu i Cechy Lęku STAI. Polska adaptacja STAI. Podręcznik. (State-Trait Anxiety Inventory manual - Polish adaptation). Warsaw: PTP.

Publisher's Note Springer Nature remains neutral with regard to jurisdictional claims in published maps and institutional affiliations. 